\title{
Deep ripping after topsoil return affects root proliferation and floristic diversity in a restored biodiverse forest after bauxite mining
}

\author{
T.D. Lardner School of Earth and Environment, The University of Western Australia, Australia
}

M. Tibbett National Soil Resources Institute, Cranfield University, UK

\begin{abstract}
This study aimed to determine whether deep ripping following the placement of overburden and topsoil materials significantly reduced in-situ soil strength, encouraged root penetration/proliferation and altered floristic diversity in a rehabilitated bauxite mine pit. Three plots located within an area that was deep-ripped after overburden and topsoil return were compared with three plots within the same mine pit that received the conventional pit floor ripping/topsoil scarification treatment. All plots were reseeded with $>150$ plant species from the local biodiverse forest. Topsoil ripping produced no significant overall effect on soil strength because the materials in the pit were very friable and had low soil strength regardless of topsoil treatment. Root abundance generally correlated better with depth than with penetration resistance.

There was interaction between soil depth and ripping treatment with respect to root abundance, indicating that the vegetation responded differently in terms of root proliferation to depth depending on whether the topsoil was deep-ripped. Roots were significantly more abundant in the top $10 \mathrm{~cm}$ of scarified profiles, but in those that received the topsoil ripping treatment, root abundances were significantly higher between 50 and $60 \mathrm{~cm}$ depth. This differential response was also highlighted by multivariate analysis of floristic data, which revealed that community composition and structure differed between topsoil ripping treatments. After 12 years, scarified plots had greater species richness, total abundance and plant density on average, but the vegetation was larger in topsoil-ripped plots. The benefits conferred by topsoil ripping appear to be highly dependent on the physical properties of the soil materials but may affect floristic diversity of the restored forest. From this the conclusion is there is a direct link between the physical treatment of soils and rehabilitation success.
\end{abstract}

\section{Introduction}

Deep ripping of mine pit floors is undertaken to alleviate compaction of pit floor materials that may have resulted from heavy machinery traffic during mining. The reported benefits of ripping include the shattering of high-strength zones and a reduction in soil bulk density (Henderson, 1989; Harrison et al., 1994; Hamza and Anderson, 2002; Mengler et al., 2006) and associated increases in air and water movement through the soil profile (Uhrie, 2001). This, in turn, facilitates deeper rooting depth by establishing vegetation, improved root architecture and increased use of deep sub-soil moisture (Rokich et al., 2001).

Undertaking a second round of ripping following topsoil and overburden placement, in addition to the deep ripping of pit floor materials, has been shown to improve the rehabilitation of bauxite mine pits in the higher rainfall jarrah forest (Koch, 2007). This ripping, which reaches a depth of approximately $0.8 \mathrm{~m}$, has been reported to remove compaction caused by soil return operations. When carried out on contour, it also creates ridges and furrows in the returned surface material, which assists in the prevention of soil erosion in the early stages of pit rehabilitation (Koch, 2007). However, not all strip mine operators practise deep ripping following topsoil return. Instead, the final stages of topsoil treatment during the rehabilitation process can involve contour scarification $(30-40 \mathrm{~cm}$ depth) using agricultural-style harrows following topsoil return. This method is used not only for erosion control and to alleviate surface compaction, but also to improve seed-soil contact. 
In 1995, a field trial was established in a rehabilitated bauxite mine pit located within the jarrah forest of southwest Western Australia. The trial was designed to assess the effects of deep ripping following topsoil and overburden return on plant establishment and growth. For the trial, the entire pit-floor was deepripped using a chisel tine with a ripline spacing of about $1.2 \mathrm{~m}$. Following return of overburden and topsoil that was sourced directly from a newly operating mine pit, the entire area was seeded with about 160 plant species that are native to the surrounding jarrah forest. An area of approximately 0.5 ha was then ripped again (on contour) using the same tine whilst the remainder of the pit was contour-scarified using harrows.

The site was revisited for assessment 12 years after the establishment of the trial. This study aimed to determine whether there had been any significant effects of the topsoil ripping treatment on in-situ soil strength, root penetration/proliferation and floristic composition.

\section{$2 \quad$ Methods}

\subsection{Pit assessments}

To facilitate sample collection and soil profile investigations, two soil pits were excavated in the topsoil ripped area and two in the control (topsoil scarified) area. Pits were excavated perpendicular to the riplines and to a maximum depth of $1.5 \mathrm{~m}$.

Within each pit, the working face was cleaned and three discrete sections of the pit wall were selected. The soil profile at each point was described in detail (soil profile morphology, soil structure) based on the Australian Soil and Land Survey Handbook (McDonald et al., 1990). Samples were taken from two to three depth intervals within each profile for analysis of chemical and physical parameters.

\subsubsection{Penetration resistance}

A $1 \mathrm{~m}^{2}$ quadrat, divided into $10 \mathrm{~cm}^{2}$ cells, was fixed to each described section of the pit face. Soil strength readings were taken within each cell using a Mecmesin Compact Force Gauge $200 \mathrm{~N}$ (tip diameter = $3.12 \mathrm{~mm}$ ). The penetrometer readings indicate the level of soil strength or resistance and can be used to infer the likely resistance to root penetration. The penetrometer measurements were taken in newtons (N) and transformed into megapascals (MPa) to enable comparisons with published data (conversion factor of 0.1306 , appropriate for the tip diameter used, was applied).

\subsubsection{Root abundance}

Root penetration and root abundance through the exposed profile were scored. For each $10 \mathrm{~cm}^{2}$ grid cell, the abundance of roots in each of the following diameter classes was recorded: fine roots $(<2 \mathrm{~mm})$, medium roots $(2-5 \mathrm{~mm})$ and coarse roots $(>5 \mathrm{~mm}$ ). A standard root abundance scoring system (McDonald et al., 1990) was used, and each cell was assigned three abundance scores, one for each root size category. A score weighting system was then employed to give a single root score per $10 \mathrm{~cm}^{2}$ area. Fine roots were weighted as ' 1 ', medium roots weighted as ' 2 ' and coarse roots weighted as ' 5 '. The abundance value of each root class was multiplied by the weighting factor, and the three values were summed to give a single root score value per cell.

The root abundance scores of the 10 cells within each $10 \mathrm{~cm}$ depth increment were summed, and the mean of these was calculated for each treatment. The summed root abundance data were log-transformed and tested by two-way ANOVA to determine if there are differences in root abundance between treatments at each depth increment.

A model was developed to estimate the percentage of total root abundance that occurs within a given interval of penetration resistance. Within each grid, root abundance scores for cells that corresponded with penetration resistances within a $10 \mathrm{~N}$ interval were summed and divided by the total root abundance across the whole $1 \mathrm{~m}^{2}$ grid. This was carried out for penetration resistances ranging between $5 \mathrm{~N}$ and $105 \mathrm{~N}$. Mean percentage root abundances for the two treatments were plotted against penetration 
resistance intervals, and curves were fitted using Sigma Plot ${ }^{\mathrm{TM}}$ version 10.0. This enabled interpolated correlation of the percentage of total root abundance in response to increasing penetration resistance.

\subsection{Material characterisation}

Distinct soil materials that were identified within the profiles of each pit were subjected to extensive laboratory analyses appropriate to an assessment of amenability to root growth. All analyses were conducted on three replicates of air-dried material that had been passed through a $2 \mathrm{~mm}$ sieve unless otherwise stated. Measurements of soil $\mathrm{pH}$ and EC were made on 1:5 soil: water extracts following methods detailed in Rayment and Higginson (1992). Particle size distribution was determined using the pipette method described in Gee and Bauder (1986). The texture of each soil material was determined by comparing the percentages of sand, silt and clay in the material against a standard texture diagram (McDonald and Isbell, 1990). The analysis was performed on a single sample $(n=1)$ of each material type from every pit $(n=1)$. Single samples $(n=1)$ of each material were analysed by $X$-ray diffraction $(X R D)$ to determine their mineralogy. A Philips PW1830 X-ray diffractometer with Cu target tube was used. Mounts of finely ground material were prepared and diffraction patterns were determined for the range $2-70$ at a scan rate of 0.02 . For mineral identification, the spacings and intensities of the diffraction traces were compared with those for the appropriate minerals given in Joint Committee on Powder Diffraction Standards (1974) data files.

The Emerson aggregate test, a measure of structural stability, was used to determine the propensity for dry aggregates of each material to slake and disperse on wetting (Emerson, 1967; 2002). The Gillman and Sumpter method (cited in Rayment and Higginson, 1992) was used to assess cation exchange capacity and from this, the effective cation exchange capacity (ECEC) was calculated (Rengasamy and Churchman, 1999). Exchangeable sodium percentage (ESP) was calculated from the ECEC. ESP is the percentage of exchangeable sodium ions that make up the total ECEC and indicates soil sodicity. Soil organic carbon was determined using the Walkley and Black method (1934), which is based on the oxidation of organic matter by dichromate in the presence of $\mathrm{H}_{2} \mathrm{SO}_{4}$.

\subsection{Floristic survey and data analysis}

Floristic data were analysed to determine if there were any significant effects of the ripping treatments on the aboveground characteristics of the vegetation communities after 12 years. Data were collected from within three replicate monitoring plots per treatment, each consisting of $204 \mathrm{~m}^{2}$ quadrats. Comparisons of plant abundance, density, cover and species richness were made between the ripping treatments and also between three forest monitoring plots located close to each other and an average $2.6 \mathrm{~km}$ from the trial. Skewness and heteroscedasticity of the data necessitated the use of the Kruskal-Wallis ANOVA on ranks. Shannon-Wiener $\left(\mathrm{H}^{\prime}\right)$, evenness $(\mathrm{J})$ and dominance $(D)$ indices were calculated to assess the floristic diversity within each treatment.

Multivariate analyses were conducted using Primer $\odot$ version 6.0. Non-metric multi-dimensional scaling (MDS) of the Bray-Curtis similarity among quadrats was used to map plot-wise centroids of community composition and structure between treatments. Permutational MANOVA (PERMANOVA) was used to detect significant differences in these characteristics between the treatments using a two-way nested model to avoid pseudo-replication and to check for significant spatial variation between plots (Anderson and Robinson, 2003). The SIMPER routine was used to determine the mean contribution of each plant species to any differences detected. Prior to testing, the data were square-root-transformed to reduce the overall effect of very abundant species. 


\section{$3 \quad$ Results}

\subsection{Soil profile morphology}

The surface soil profiles within the trial area exhibited little variation in terms of main morphological characteristics, regardless of the imposed ripping treatment. Profiles across the pit were characterised by three identifiable materials: a sandy 'topsoil' overlaying a rock/clay 'overburden' regolith and a third 'clay' material that was located in only one soil pit within the topsoil ripped area. There was little visual evidence of the topsoil ripping on soil structure apart from an occasional undulating boundary between the topsoil and the underlying soil layers/materials.

The topsoil was a sandy, single-grained material dominated by pisolithic coarse fragments $(2-5 \mathrm{~mm})$. The depth of the topsoil layer varied from 10 to $40 \mathrm{~cm}$ across the trial, and the boundary between the topsoil and underlying regolith was reasonably distinct. The overburden regolith was friable, fractured rock with a small amount $(<25 \%)$ of interstitial 'clay' matrix material. The 'clay' matrix was predominantly singlegrained, although weak to moderate aggregation was apparent in some of the sampled areas. Coarse fragments (>75\%) were sub-angular/sub-rounded and $5-20 \mathrm{~mm}$ in size. This material extended from beneath the topsoil to the base of the pit in all but one site, where it overlaid the third 'clay' material. This material was a well-structured, platy 'clay' containing approximately $10 \%$ sub-angular/sub-rounded coarse fragments $(5-50 \mathrm{~mm})$. It extended from a depth of approximately $60 \mathrm{~cm}$ to the base of the pit, and the boundary between it and the overlying regolith was diffuse.

\subsection{Material characterisation}

\subsubsection{Particle size distribution and soil texture}

The topsoil had a high sand content, with similar amounts of silt and clay (Table 1). It was classed as sand in the topsoil ripped trial area and loamy sand in the control area, but overall differences in the material composition were minor. Mean coarse fragment content of the topsoil exceeded $60 \%$ of total mass. The regolith material had higher clay and silt contents than the topsoil, although the fine earth component was still dominated by sand-sized particles (Table 1). Soil texture ranged from a sandy loam to clay loam throughout the trial area, and the material was approximately $70 \%$ coarse fragments. The third material, located in only one of the four soil pits, was a clay loam. It consisted of $48 \%$ sand with nearly equal amounts silt and clay (Table 1). As with the other two soil materials, coarse fragment content was high (>60\%). Overall, the topsoil and overburden regolith materials were generally comparable in each of the four assessed areas of the mine pit.

\subsubsection{Mineralogy (XRD)}

The topsoil and overburden regolith materials were both dominated by quartz and gibbsite, which are both non-clay minerals, with varying amounts of kaolinite and goethite/hematite (iron oxides). Anatase was present in the majority of samples, and halloysite was present in trace amounts in one sample of the regolith material. The 'clay' material, found only in one pit within the topsoil ripped area, was dominated by gibbsite and goethite/hematite, with approximately $15-20 \%$ of both kaolinite and quartz (Table 1). Gibbsite is often the predominant mineral in bauxite deposits and also occurs in laterites in association with iron oxides (Moore, 2004a).

\subsubsection{Soil structural stability}

The topsoil material had very high structural stability, although this was coupled with high water repellency, presumably resulting from the incorporation of hydrophobic organic matter (Moore, 2004b). The low clay content of the topsoil and the lack of sodicity (Table 1) probably contributed to the lack of observed dispersion. It should be noted that although the tested aggregates were stable, aggregation was low in this material. The overburden regolith was found to be sodic (Table 1). However, the test indicated that soil stability was generally good for these materials unless severely disturbed. This is typical of acidic 
soils with long-range attractive forces between clay particles that cause flocculation even when disturbed (Emerson, 2002). The deeper clay material was structurally unstable, and aggregates immediately slaked and dispersed on wetting. This indicates an easily degraded soil, and ripping has the potential to disturb any fragile macrostructure present and contribute to structural decline. The cause of this structural instability is likely to be related to the highly sodic nature of the material (Table 1); high levels of sodium favour aggregate slaking and dispersion, which reduces soil conductivity and porosity (Moore, 2004a).

\subsubsection{Soil chemical properties}

All three materials were slightly to moderately acidic (Slattery et al., 1999), as is typical of Jarrah forest soils from the region (Ward, 2000; McArthur, 1991; Dell et al., 1989). The pH of the soils ranged from approximately 5.5 to 6.2 , with acidity generally increasing with depth in the profile. All of the materials were found to be non-saline (Table 1).

The effective cation exchange capacity is an indirect measure of soil fertility because it provides an indication of the soil's ability to retain and exchange ions important in plant nutrition (Tucker, 1983). The ECEC of all materials was generally low. The most abundantly available cations were $\mathrm{Ca}^{2+}$ and $\mathrm{Mg}^{2+}$, while exchangeable $\mathrm{K}^{+}$and $\mathrm{Al}^{3+}$ were very low. The topsoil had the highest ECEC and the overburden material, the lowest (Table 1). It should be noted that the soils of the Jarrah forest are inherently nutrient-poor, and these results are therefore typical of soils from the region (Hingston et al., 1981; Turton et al., 1962).

The organic carbon content of the topsoil material was moderate (Table 1) but was somewhat lower than the c. $2.5 \%$ to c. $4.5 \%$ that would be expected for local jarrah forest topsoil (Lardner and Tibbett, 2011). The organic carbon content decreased sharply with depth as expected. The organic carbon concentration of the underlying material was extremely low, as was that of the clay material (Table 1). However, according to Purdie (1998), organic carbon concentrations between $0.1 \%$ and $0.5 \%$ are moderate for these horizons in Western Australian soils.

Table 1 Major characteristics of the three soil materials present in the trial pit; mean values for each material type are indicated in parentheses where appropriate

\begin{tabular}{cccc}
\hline & Topsoil & Overburden & Clay Material \\
\hline Texture & Sand-Loamy sand & Clay loam-Sandy loam & Clay loam \\
Coarse fragment & $63 \%$ & $72 \%$ & $64 \%$ \\
Sand & $89 \%$ & $65 \%$ & $48 \%$ \\
Silt & $6 \%$ & $15 \%$ & $24 \%$ \\
Clay & $5 \%$ & $20 \%$ & $28 \%$ \\
pH (soil: water) & 6.24 & 5.95 & 5.5 \\
EC (dS m ${ }^{-1}$ ) & 0.08 & 0.02 & 0.04 \\
Emerson's class & 8 (stable) & 6 (stable) & 1 (unstable) \\
Sodicity (ESP \%) & Non-sodic (2.8\%) & Sodic (13.3\%) & Highly sodic (33.7\%) \\
ECEC (meq 100g ${ }^{-1}$ ) & Low (4.30) & Low (0.40) & Low (0.85) \\
Organic carbon (\%) & Moderate (1.82) & Extremely low (0.34) & Extremely low (0.32) \\
Major minerals & Gibbsite, quartz & Quartz, gibbsite & Gibbsite, goethite/ \\
& & & haematite, quartz \\
\hline
\end{tabular}




\subsection{Root penetration and soil strength}

As may be expected, root abundance was greater towards the top of the soil profiles and decreased marginally with depth. Jarrah forest vegetation is typically deep-rooted, and root penetration beyond the base of the soil pit $(1.5 \mathrm{~m})$ was noted in all cases. Small isolated areas of low or no root growth were evident in all sections of pit face that were examined ( 6 in TS ripped area, 6 in control area). These did not necessarily correspond to regions of higher penetration resistance. Rather, the spatial heterogeneity in root distribution may have resulted from preferential root growth along existing cracks and fissures.

In both the topsoil ripped and control areas, penetration resistance increased with depth. The upper $10-50 \mathrm{~cm}$ of the profile had very low strength (<10 N on average), irrespective of treatment. Below this, resistance increased progressively with depth, although the relationship was more strongly linear in the control area. There was much more variation in penetration resistance below $60 \mathrm{~cm}$ in the topsoil ripped treatment than in the control. This was caused by isolated pockets of high soil strength in pit two of this treatment. Despite this effect, mean penetration resistance did not exceed $40 \mathrm{~N}(5.2 \mathrm{MPa})$ for either treatment.

There was a weak but highly significant negative correlation between penetration resistance and root abundance in both the topsoil ripped and conventionally ripped areas $(R=-0.28 ; p<0.001)$. Root abundance scores $>5$ were generally associated with penetration resistance values of $<20 \mathrm{~N}(2.6 \mathrm{MPa})$. Similarly, very high root scores $(>10)$ consistently occurred in zones with very low soil strength values ( $<10 \mathrm{~N} ; 1.3 \mathrm{MPa}$ ). However, root proliferation at penetration resistances $>60 \mathrm{~N}$ (7.8 MPa) seemed to occur only in the topsoil ripped profiles, with the exception of one outlier in the control. Root proliferation appeared to have been less restricted by soil strength in the topsoil ripped treatment (Figure 1). At low penetration resistance, root abundance between the treatments was similar; $50 \%$ of roots were located where penetration resistance was at or below $4.2 \mathrm{~N}(0.55 \mathrm{MPa})$ in the control and $4.5 \mathrm{~N}(0.59 \mathrm{MPa})$ in the topsoil ripped area. But with increasing soil strength, the reduction in root abundance was more dramatic in the control, where $95 \%$ of roots were restricted to zones in the profile where penetration resistance was below $17.3 \mathrm{~N}(2.26 \mathrm{MPa})$. In contrast, about $18 \%$ of roots in the topsoil ripped treatment were located in zones where the penetration resistance was higher than this level (Figure 1). 


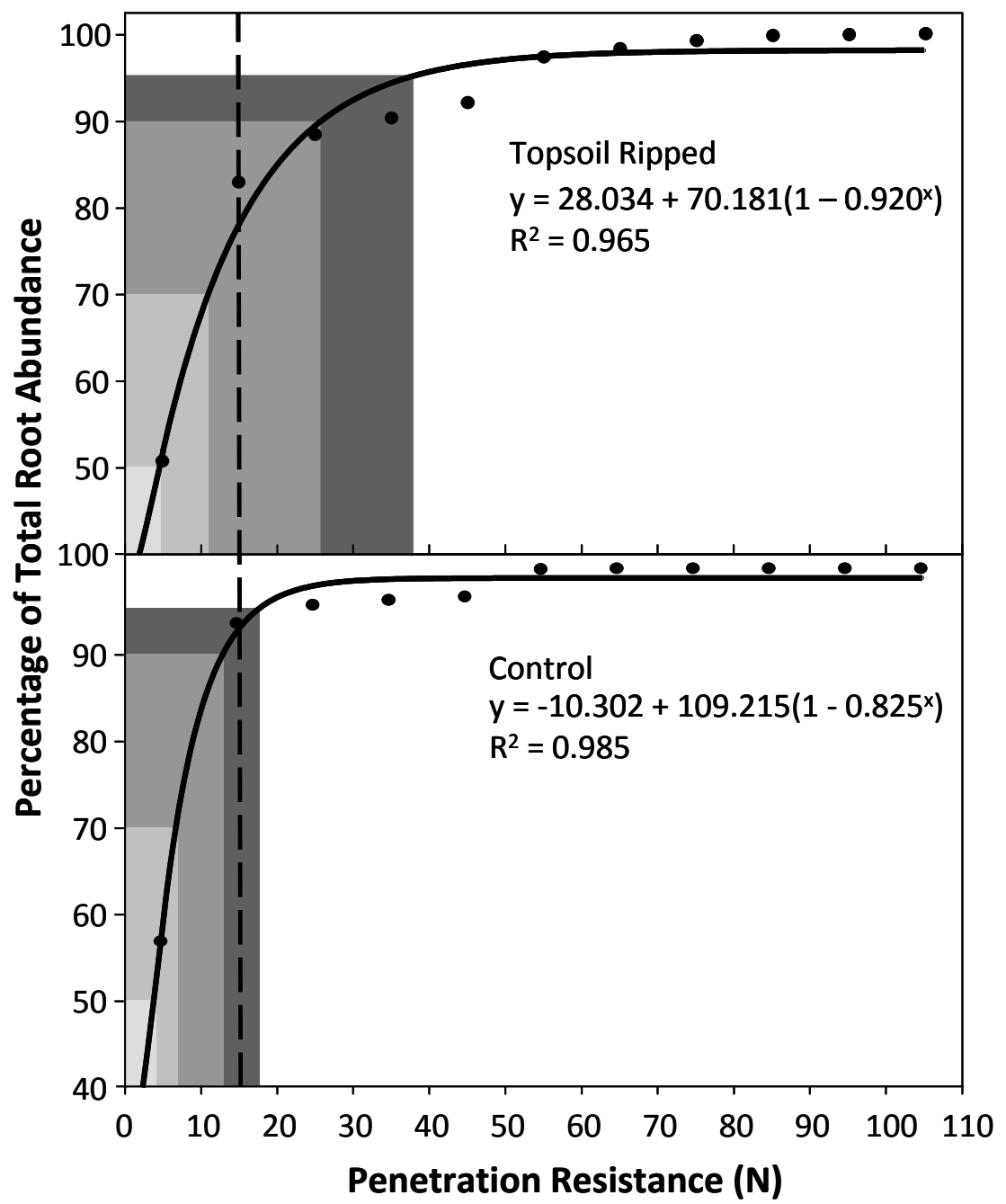

Figure 1 Exponential regression curves of the percentage of roots within topsoil ripped (top) and control (bottom) profiles that were located where the penetration resistance was below a given level - shaded areas represent penetration resistances below which 50\%, 70\%, 90\% and $95 \%$ of roots were established (light grey to dark grey respectively); dashed line represents a widely accepted penetration resistance threshold at which root growth of agricultural species becomes inhibited

No significant difference in penetration resistance was found between the two treatments at any depth ( $p>0.05$; Figure 2). However, roots were significantly more abundant in the top $10 \mathrm{~cm}$ of the control profiles than in those that received the topsoil ripping treatment $(P<0.01$, Figure 2$)$. Conversely, between $50 \mathrm{~cm}$ and $60 \mathrm{~cm}$, root abundance scores were significantly higher in the topsoil ripped profiles than in the controls $(P<0.05)$. Below $80 \mathrm{~cm}$, root abundance scores for the control and the topsoil ripped profiles were similar (Figure 2). Overall, there was significant interaction between soil depth and ripping treatment with respect to root abundance $(P=0.002)$, indicating that the vegetation has responded differently in terms of root proliferation to depth depending on whether the topsoil was ripped or not. 


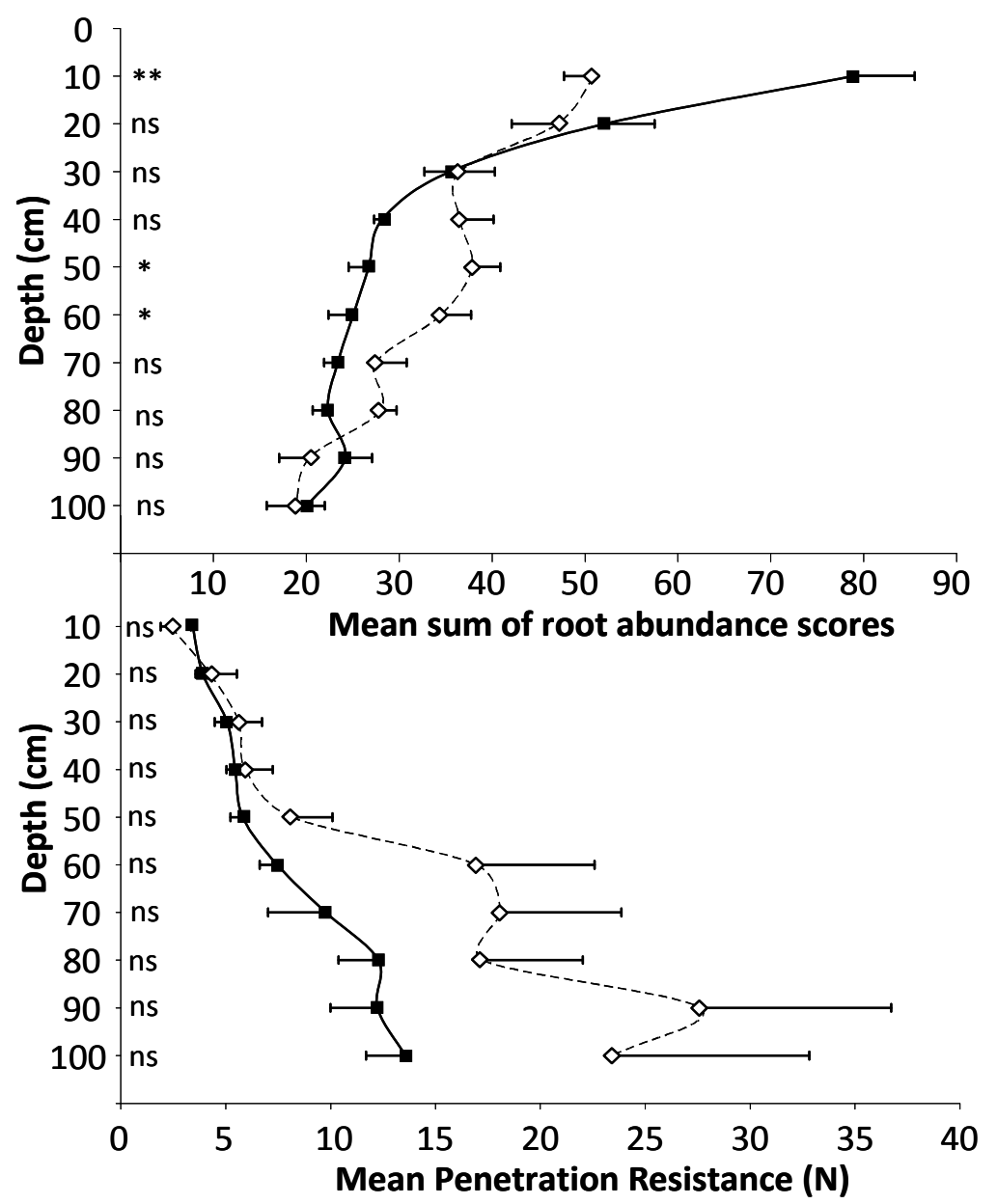

Figure 2 Changes in the mean sum of root abundance scores (top) and mean penetration resistance (bottom) with depth in topsoil ripped plots $\left(-\diamond_{-}^{-}\right)$and control plots $(-)-$ symbols along the $y$ axis represent results of Tukey's multiple comparisons following twoway ANOVA where applicable $(\alpha=0.05): n s=p>0.05 ; *=p<0.05 ; * *=p<0.01$ while bars represent standard error of the mean; note that there was significant interaction between depth and ripping treatment with respect to root abundance $(P=0.002)$

\subsection{Floristic analysis}

Twelve years after rehabilitation establishment, species richness, total plant abundance and total plant density were greater in the control areas (Table 2) where there were seven more species present, 351 more individual plants counted, and plant density was about 1.5 times that of topsoil ripped areas. These differences, however, were not statistically significant $(P>0.05)$. After 12 years, the vegetation complexes in both ripping treatments remained dissimilar to the unmined forest; the unmined forest plots exhibited significantly greater species richness (106 species), total plant abundance $(3,608$ plants) and plant density (about 4-5 times greater) than plots within either of the ripping treatments $(P<0.001$; Table 2). Marginally higher diversity and evenness was found in topsoil ripped areas with Shannon-Wiener index $\left(\mathrm{H}^{\prime}\right)$ and evenness $(\mathrm{J})$ values of 3.03 and 0.76 respectively compared with 2.88 and 0.7 for the control areas. This indicates a more even distribution of individual plants among species in the topsoil ripped areas and a slight tendency towards domination by a few species within the controls, as indicated by the higher dominance figure (Table 2). This effect appears to be caused by a greater relative abundance of Acacia celastrifolia and Petrophile heterophylla within control areas. There was a more even distribution of individuals among species and greater diversity in the unmined forest plots than in either ripping treatment (Table 2).

There was marginally but not statistically $(P>0.05)$ greater total foliage cover within topsoil ripped areas (48.7\%) in comparison to the control areas (38.8\%). This, coupled with lower density, may indirectly 
indicate slightly greater mean plant growth or aboveground biomass in the topsoil ripped areas. Cover in both treatments was also similar to that of the unmined forest plots $(P>0.05)$, which had total cover of $47.8 \%$ (Table 2).

Table 2 Floristic indices of control, topsoil ripped, and unmined forest plots - only the living flora were considered; superscripts indicate homogenous subsets at $\alpha=0.05$; diversity indices were not tested

\begin{tabular}{cccc}
\hline Diversity Measure & Control & Topsoil Ripped & Unmined \\
\hline Species richness & $62^{\mathrm{b}}$ & $55^{\mathrm{b}}$ & $106^{\mathrm{a}}$ \\
Total abundance & $1000^{\mathrm{b}}$ & $649^{\mathrm{b}}$ & $3608^{\mathrm{a}}$ \\
Total cover (\%) & 38.8 & 48.7 & 47.8 \\
Density-all species (plants $\left.\mathrm{m}^{-2}\right)$ & $4.17^{\mathrm{b}}$ & $2.71^{\mathrm{b}}$ & $15.03^{\mathrm{a}}$ \\
Shannon-wiener index $\left(\mathrm{H}^{\prime}\right)$ & 2.88 & 3.03 & 3.77 \\
Evenness $(\mathrm{J})$ & 0.7 & 0.76 & 0.81 \\
Dominance $(1-\mathrm{J})$ & 0.3 & 0.24 & 0.19 \\
\hline
\end{tabular}

In dividing the percentage cover produced by a species by the number of individuals of that species, a pattern emerges that suggests that, with the exception of $A$. celastrifolia, the vegetation is generally larger in topsoil ripped plots than in the controls (Table 3). Eucalyptus marginata, for example, projects 2.6 times as much cover per individual in the topsoil ripped treatment in comparison with their counterparts in the control (Table 3).

Multivariate analysis by PERMANOVA indicated that the plant community that developed within the topsoil ripped area differed in composition (Pseudo $\mathrm{F}=2.26$; $\mathrm{P}(\mathrm{Perm})=0.025$ ) to that which developed where topsoil was scarified. Topsoil scarified (control) plots were dominated by $A$. celastrifolia to a much greater extent than topsoil ripped plots, where Gastrolobium bilobum, Melaleuca parviceps and Calothamnus quadrifidus were a more prominent feature of the vegetation (Figure 3 ). In terms of relative species abundance, $A$. celastrifolia accounted for about $52 \%$ of the similarity between plots within the control treatment, whereas much of the similarity between topsoil ripped plots was caused by a handful of species, A. celastrifolia among them (17.4\% contribution to similarity). This was the principal compositional difference between the two treatments (Figure 3).

There were also differences in dispersion effects between plots within the two treatments $(F=3.16$; $P_{(\text {perm })}=0.02$ ). There was greater variation in floristic composition within topsoil ripped plots than within control plots (see the difference in the spread of points between treatments in Figure 3); however, the within-plot dispersion was consistent between the topsoil ripped plots, and this contributed to the similarity between them (see MDS in Figure 3). Conversely, there was less compositional variation within control plots, but the extent of dominance by $A$. celastrifolia varied considerably, contributing to the differences between them (Figure 3). This was also an important contributor to the difference between the treatments.

Community structure differed significantly between the two treatments (Pseudo $F=4.94 ; P(P e r m)=0.0004)$, but in this case dispersion effects between plots did not contribute to this difference (Pseudo $F=1.23$; $\left.P_{(\text {perm })}=0.38\right)$. In the control, the overwhelming majority of cover was provided by $A$. celastrifolia, which contributed more than $50 \%$ of the Bray-Curtis similarity in structure between plots. In topsoil ripped plots, about $58 \%$ of the Bray-Curtis similarity in structure between plots was shared between G. bilobum and $M$. parviceps. The keystone species E. marginata featured more prominently in the topsoil ripped treatment, where it was more abundant and projected much more cover (Figure 3 and 4). 
Table 3 Total abundance (a) and mean percentage cover per plant within quadrats (b) of control and topsoil ripped plots at 12 years of age for six species that contribute most to the dissimilarity between the two treatments; standard error of mean cover per plant for each species is in parentheses

\begin{tabular}{lccc}
\hline \multicolumn{1}{c}{ (a) } & \multicolumn{3}{c}{ Total Abundance } \\
\multicolumn{1}{c}{ Species } & Control & Topsoil Ripped & Difference \\
\hline Acacia celastrifolia & 237 & 56 & -181 \\
Bossiaea ornata & 21 & 34 & 13 \\
Calothamnus quadrifidus & 27 & 47 & 20 \\
Eucalyptus marginata & 10 & 13 & 3 \\
Gastrolobium bilobum & 11 & 29 & 18 \\
Petrophile heterophylla & 125 & 23 & -102 \\
\hline \multicolumn{1}{c}{ (b) } & \multicolumn{1}{c}{ Mean Per Cent Cover per Plant } \\
\multicolumn{1}{c}{ Species } & Control & Topsoil Ripped & Proportional \\
& & $1.10(0.29)$ & -2.69 \\
\hline Acacia celastrifolia & $2.96(0.47)$ & $0.16(0.05)$ & 2.90 \\
Bossiaea ornata & $0.05(0.02)$ & $1.95(0.79)$ & 2.55 \\
Calothamnus quadrifidus & $0.76(0.36)$ & $4.15(1.67)$ & 2.64 \\
Eucalyptus marginata & $1.57(0.82)$ & $6.42(1.66)$ & 3.76 \\
Gastrolobium bilobum & $1.71(0.95)$ & $2.86(1.01)$ & 1.99 \\
Petrophile heterophylla & $1.44(0.48)$ & & \\
\hline
\end{tabular}



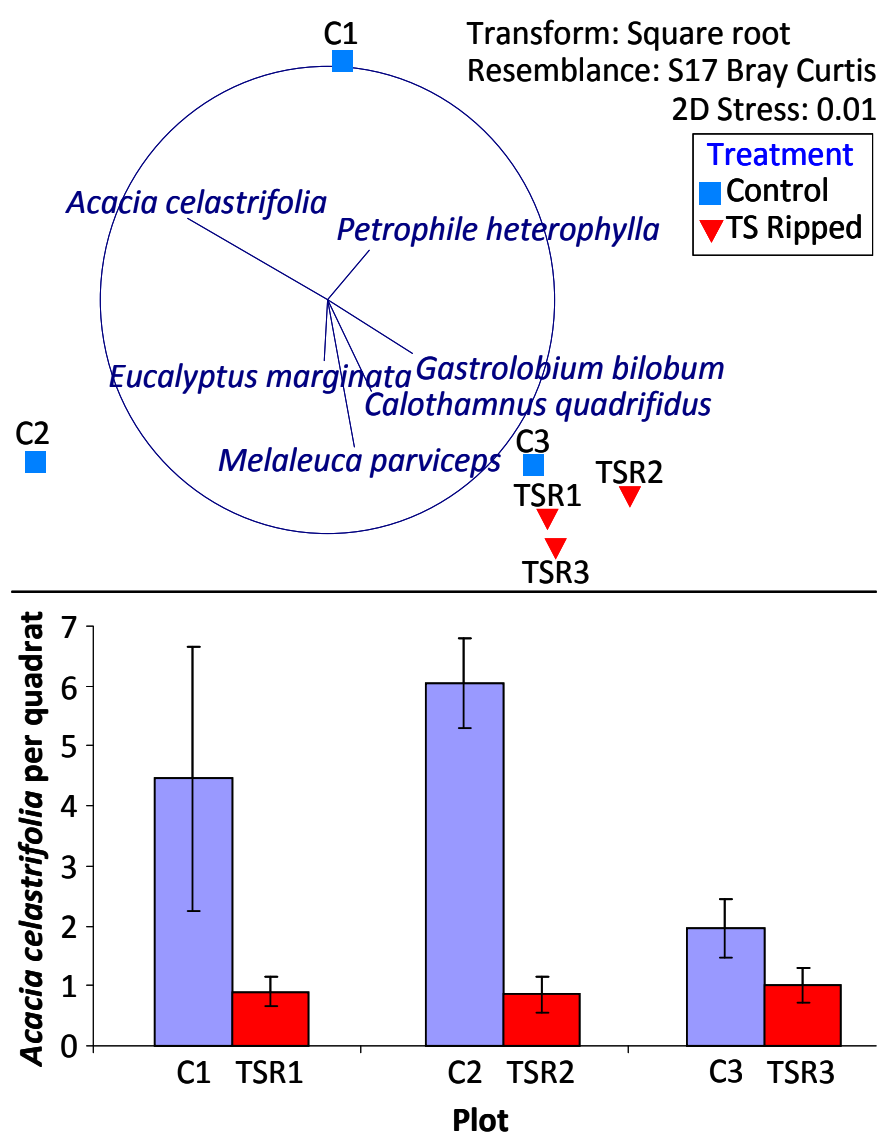

Figure 3 Non-metric multi-dimensional scaling ordination of plot centroids based on relative species abundances (top) - vectors represent the direction and intensity of Spearman rank correlations for dominant species at $\mathrm{R} \geq 0.4$ and the mean number of $A$. celastrifolia plants per quadrat within control plots (blue columns) and topsoil ripped plots (red columns)(bottom); bars represent standard error of the mean

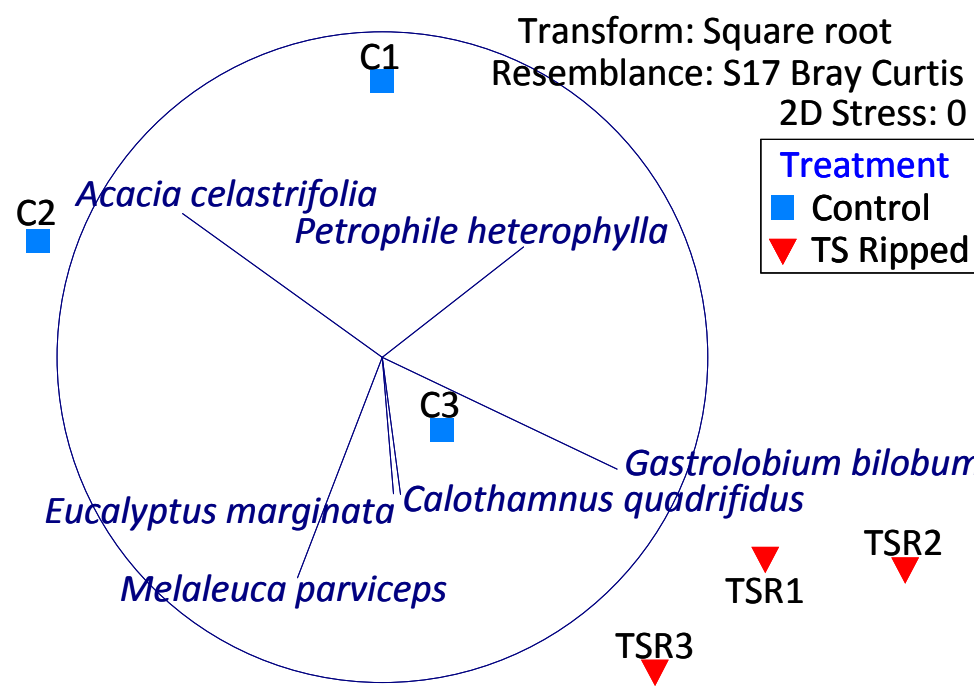

Figure 4 Non-metric multidimensional scaling ordination of plot centroids comparing plant community structure based on species cover data from within control and topsoil ripped treatments. Vectors represent the direction and intensity of Spearman rank correlations for dominant species at $R \geq 0.4$ 


\section{$4 \quad$ Discussion}

There was little evidence of topsoil ripping effects on soil structure or soil strength within the trial pit. Soil strength was consistently low (mean max. $<40 \mathrm{~N}$ ) across all the examined pits, irrespective of the imposed ripping treatment, and very few of the recorded values were high enough to critically limit the root growth of Jarrah forest species. However, penetration resistances were generally higher than the critical limit to root growth of an agricultural species such as cotton (Taylor and Burnett, 1964), and are about the soil strength threshold at which root proliferation of young jarrah forest vegetation was found by Worthington et al. (2011) to become inhibited. Worthington et al. (2011) found that $70 \%$ of roots in young jarrah forest rehabilitation were located in soil with penetration resistances below $36.9 \mathrm{~N}(4.8 \mathrm{MPa})$. Others have cited a penetration resistance of $2 \mathrm{MPa}(15.3 \mathrm{~N})$ as being critically limiting to root growth in woody agricultural species (Atwell, 1993; Bengough et al., 2006, 2011; daSilva et al., 1994; Materechera et al., 1991). Similarly, Sinnett et al. (2008) found that about $70 \%$ of roots in four northern hemisphere tree species grew in soil where penetration resistance was lower than $2 \mathrm{MPa}$, while Misra and Gibbons (1996) noted a $71 \%$ reduction in the primary root length of $E$. nitens when penetration resistance increased from $0.4 \mathrm{MPa}$ $(3.1 \mathrm{~N})$ to $4.2 \mathrm{MPa}(32.2 \mathrm{~N})$. Here, the majority of roots (i.e., more than $50 \%)$ were growing in soil where the penetration resistance was below $4.4 \mathrm{~N}(0.57 \mathrm{MPa})$, and $70 \%$ were located where it was under $8.6 \mathrm{~N}$ (1.12 MPa).

Roots were statistically more abundant in the upper $10 \mathrm{~cm}$ of the control profile, whereas at $50-60 \mathrm{~cm}$ depth, root abundance was greatest in the topsoil ripped profile. The significant interaction between soil depth and ripping treatment with respect to root abundance suggests that topsoil ripping could have encouraged faster root penetration to greater depth during establishment, resulting in more-abundant roots deeper in the profile 12 years later. This inference is supported by the floristic analysis, which demonstrates that the vegetation in the topsoil ripped treatment is generally larger (and potentially deeper-rooted) than in the control. This is interesting, given that the vegetation in the topsoil ripped treatment appears to have established a larger proportion of its roots in zones of higher soil strength than the vegetation in the control. Although not significant, there does appear to be a trend towards greater soil strength below $50 \mathrm{~cm}$ in the topsoil-ripped treatment.

There were not only differences in community structure between the two treatments, but they differed in composition also. The topsoil scarified controls were dominated by $A$. celastrifolia, but the topsoil ripped treatment appeared to host a more even mix of species and consistently displayed greater variation in relative species abundances across the treatment area. Given this observation, it seems possible that the topsoil ripping treatment may have buried a proportion of $A$. celastrifolia seed originating from the direct return topsoil (as well as those of other species), resulting in reduced seedling emergence and thus reduced abundance. This reduction in the abundance of $A$. celastrifolia may then have allowed species in the applied seed mix to predominate in the topsoil ripped plots. Despite the botanical differences between the two treatments, neither treatment was any more similar to plots representing the nearby unmined forest than the other.

The statistical differences in root abundance between the two treatments appear to have occurred at the surface, where most $P$ foraging and water capture would occur, and at depths where the greatest impact of tine could be expected. This suggests that topsoil scarification assists root proliferation nearer the soil surface, while deep ripping after topsoil return produces a similar effect deeper down. However, average penetration resistance did not exceed $40 \mathrm{~N}(5.2 \mathrm{MPa})$ in either treatment, and there was no statistical difference in penetration resistance between the treatments at any depth. Thus the soil materials seem to have responded equally well to both treatments, but the developing vegetation community nevertheless appears to have made a distinction between them. This is particularly evident in the suppression of $A$. celastrifolia in the topsoil ripped treatment. This legume species is known to become dominant in rehabilitation at mine sites close to where it occurs naturally (Beazley et al., 2006; Davis 2005). This investigation has provided clear evidence that different physical treatments of similar materials can have significant effects on the composition and structure of the developing vegetation within bauxite mine pit rehabilitation. 


\section{References}

Anderson, M.J. and Robinson, J. (2003) Generalised discriminant analysis based on distances, Australian and New Zealand Journal of Statistics, Vol. 45, pp. 301-318.

Atwell, B.J. (1993) Response of roots to mechanical impedance, Environmental and Experimental Botany, Vol. 33, pp. $27-40$.

Beazley, R., Dudley, A., Braimbridge, M.F., Ryan, M. and Tibbett, M. (2006) Phosphorus application on a rehabilitated bauxite mine: the optimal rate for two key Jarrah forest species - Acacia celastrifolia and Eucalyptus marginata, Centre for Land Rehabilitation, University of Western Australia.

Bengough, A.G., Bransby, M.F., Hans, J., McKenna, S.J., Roberts, T.J. and Valentine, T.A. (2006) Root responses to soil physical conditions: growth dynamics from field to cell, Journal of Experimental Botany, Vol. 57, pp. 437-447.

Bengough, A.G., McKenzie, B.M., Hallett, P.D. and Valentine, T.A. (2011) Root elongation, water stress, and mechanical impedance: a review of limiting stresses and beneficial root tip traits, Journal of Experimental Botany, Vol. 62, pp. 59-68.

daSilva, A.P., Kay, B.D. and Perfect, E. (1994) Characterization of the least limiting water range of soils, Soil Science Society of America Journal, Vol. 58, pp. 1775-1781.

Davis, S. (2005) Rehabilitation of a post mining jarrah forest: native seedling establishment response to timing of fertiliser application, method of application and fertiliser type, Honours thesis, University of Western Australia.

Dell, B., Havel, J.J. and Malajczuk, N. (editors) (1989) The Jarrah forest: a complex Mediterranean ecosystem, Boston, Kluwer Academic Publishers.

Emerson, W. (1967) A classification of soil aggregates based on their coherence in water, Australian Journal of Soil Research, Vol. 5, pp. 47-57.

Emerson, W.W. (2002) Emerson dispersion test, in Soil Physical Measurement and Interpretation for Land Evaluation, N. McKenzie, K. Coughlan and H. Cresswell (eds), CSIRO Publishing, Collingwood, pp. 190-199.

Gee, G.W. and Bauder, J.W. (1986) Particle size analysis, in Methods of Soil Analysis (Vol 1): Physical and Mineralogical Methods, A. Klute (ed), American Society of Agronomy, Madison, Wisc., pp. 383-412.

Hamza, M.A. and Anderson, W.K. (2002) Improving soil physical fertility and crop yield on a clay soil in Western Australia, Australian Journal of Agricultural Research, Vol. 53, pp. 615-620.

Harrison, D.F., Cameron, K.C. and McLaren, R.G. (1994) Effects of subsoil loosening on soil physical-properties, plant-root growth, and pasture yield, New Zealand Journal of Agricultural Research, Vol. 37, pp. 559-567.

Henderson, C.W.L. (1989) Using a penetrometer to predict the effects of soil compaction on the growth and yield of wheat on uniform, sandy soils, Australian Journal of Agricultural Research, Vol. 40, pp. 497-508.

Hingston, F.J., Dimmock, G.M. and Turton, A.G. (1981) Nutrient distribution in a jarrah (Eucalyptus marginata) ecosystem in southwest Western Australia, Forest Ecology and Management, Vol. 3, pp. 183-207.

Koch, J.M. (2007) Alcoa's mining and restoration process in South Western Australia, Restoration Ecology, Vol. 15, pp. S11-S16.

Lardner, T.D. and Tibbett, M. (2011) Fertiliser Application to Jarrah Forest Rehabilitation Field Trial 2 - Boddington Bauxite Mine Inception Report, Centre for Land Rehabilitation, University of Western Australia.

McArthur, W.M. (1991) Reference Soils of South-western Australia, Perth, W.A., Western Australia, Department of Agriculture.

McDonald, R.C. and Isbell, R.F. (1990) Soil profile, in Australian Soil and Land Survey Field Handbook, R.C. McDonald, R.F. Isbell, J.G. Speight, J. Walker and M.S. Hopkins (eds), Inkata Press, Melbourne, pp. 103-152.

McDonald, R.C., Isbell, R.F., Speight, J.G., Walker, J. and Hopkins, M.S. (eds) (1990) Australian Soil and Land Survey Field Handbook, Inkata Press, Melbourne.

Materechera, S.A., Alston, A.M., Kirby, J.M. and Dexter, A.R. (1992) Influence of root diameter on the penetration of seminal roots into a compacted subsoil, Plant and Soil, Vol. 144, pp. 297-303.

Mengler, F.C., Kew, G.A., Gilkes, R.J. and Koch, J.M. (2006) Using instrumented bulldozers to map spatial variation in the strength of regolith for bauxite mine floor rehabilitation, Soil \& Tillage Research, Vol. 90, pp. 126-143.

Misra, R.K. and Gibbons, A.K. (1996) Growth and morphology of Eucalyptus seedling roots, in relation to soil strength arising from compaction, Plant and Soil, Vol. 182, pp. 1-11.

Moore, G. (2004a) Distinctive morphological features and their agricultural significance, in Soil Guide: A Handbook for Understanding and Managing Agricultural Soil, G. Moore (ed), National Landcare and Department of Agriculture, Perth, Western Australia, pp. 43-52.

Moore, G. (2004b) Water repellence, in Soil Guide: A Handbook for Understanding and Managing Agricultural Soil, G. Moore (ed), National Landcare and Department of Agriculture, Perth, Western Australia, pp. 53-63.

Purdie, B.R. (1998) Understanding and interpreting soil chemical and physical data, in Soil Guide: A Handbook for Understanding and Managing Agricultural Soil, G. Moore (ed), National Landcare and Department of Agriculture, Perth, Western Australia.

Rayment, G.E. and Higginson, F.R. (1992) Australian Laboratory Handbook of Soil and Water Chemical Methods, Inkata Press, Melbourne.

Rengasamy, P. and Churchman, G.J. (1999) Cation exchange capacity, exchangeable cations and sodicity, in Soil Analysis: An Interpretation Manual, K.I. Peverill, L.A. Sparrow and D.J. Reuter (eds), CSIRO Publishing, Collingwood, pp. 147-155.

Rokich, D.P., Meney, K.A., Dixon, K.W. and Sivasithamparam, K. (2001) The impact of soil disturbance on root development in woodland communities in Western Australia, Australian Journal of Botany, Vol. 49, 169-183.

Sinnett, D., Morgan, G., Williams, M. and Hutchings, T.R. (2008) Soil penetration resistance and tree root development, Soil Use and Management, Vol. 24, pp. 273-280.

Slattery, W.J., Conyers, M.K. and Aitken, R.L. (1999) Soil pH, aluminium, manganese and lime requirement, in Soil Analysis: An Interpretation Manual, K.I. Peverill, L.A. Sparrow and D.J. Reuter (eds), CSIRO Publishing, Collingwood, pp. 103-125. 
Taylor, H.M. and Burnett, E. (1964) Influence of soil strength on the root-growth habits of plants, Soil Science, Vol. 98, pp. 174-180. Tucker, B.M. (1983) Basic exchangeable cations, in Soils, An Australian Viewpoint, CSIRO, Melbourne.

Turton, A.G., Marsh, N.L., McKenzie, R.M. and Mulcahy, M.J. (1962) The Chemistry and Mineralogy of Lateritic Soils in the Southwest of Western Australia, Soil Publication No. 20, CSIRO Australia.

Uhrie, J.L. (2001) Evaluation of deeply ripping truck-dumped copper leach stockpiles, Mining Engineering, Vol. 53, pp. 54-56.

Walkely, A. and Black, I.A. (1934) An examination of the Degtjareff method for determining soil organic matter and a proposed modification of the chromic acid titration method, Soil Science, Vol. 37, pp. 29-38.

Ward, S.C. (2000) Soil development on rehabilitated bauxite mines in south-west Australia, Australian Journal of Soil Research, Vol. 38, pp. 453-464.

Worthington, T., Lardner, T.D., Braimbridge, M.F., and Tibbett, M. (2011) Second assessment of the effects of different ripping practices on the physical properties of pit floor materials, Centre for Land Rehabilitation, University of Western Australia. 